\title{
TÖKEL, Dursun Ali (2019). Divan Şairi Diyor ki. İstanbul: Ketebe Yayınları, $263 \mathrm{~s}$.
}

\author{
Kamil Ali GIYNAŞ*
}

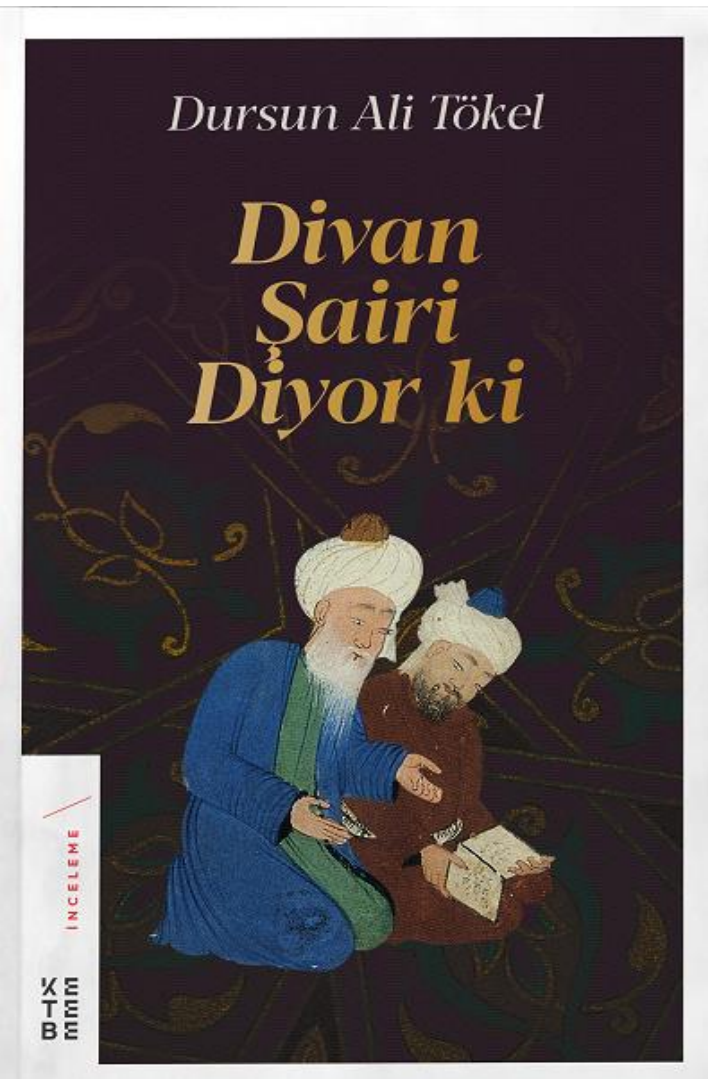

Divan Şairi Diyor Ki, Dursun Ali TÖKEL'in muhtelif edebiyat dergilerinde yayımlanmış yazılarının toplandığ bir kitap. Kitapta 21 yazı var.

İlk yazının başlığı "Dede Korkut ve Güvâhî Der ki: Ailede Mutluluk böyle sağlanır"dır. $\mathrm{Bu}$ yazıda ailede mutluluğun formülü Dede Korkut Hikâyeleri'ndeki Dirse Han ile Güvâhî'nin Pend-nâme'sindeki Behlül Dânâ hikâyesiyle anlatılmaktadır.

İkinci yazı "Mevlânâ, Gelibolulu Âlî, Dostoyevski, France, Firdevsî, Zerdüşt Diyor Ki: Şeytan İşte Böyle Kandırır" başlı̆̆ını taşımaktadır. $\mathrm{Bu}$ yazıda şeytanın insanı nasıl kandırdığ Mevlânâ'nın Mesnevî'sinde Muaviye ile şeytan arasında, Gelibolulu Âlî̀nin Tuhfetü'l-Uşşâk mesnevisinde peygamber ile şeytan arasında, Anatole France'1n Thais adl1 romanında Pafnüs ile şeytan arasında,

Dostoyevski'nin Karamazov Kardeşler'inde İvan ile şeytan arasında, Firdevsî'nin Şehnâme'sinde Dahhâk ile şeytan arasında geçen hikâyeler vasıtasıyla anlatılıışır. Ayrıca, Zerdüştlüğün kutsal kitabı Avesta'da "Geciktirmek" ve "Sonra" şeytanlarının varlığı ifade edilmiştir.

Üçüncü yazı "Necâtî Diyor Ki: Benlik Şarap, Zikir Karanfildir" başlığını taşımaktadır. Bu yazıda yazar, günümüzde çok yaygın olarak sorulan "Tanrı neden sürekli kendisine yalvarmamızı istiyor? Bu egoistçe bir davranış değil mi?" sorusuna asırlar önce Necâtî’nin verdiği cevapları yorumluyor.

\footnotetext{
${ }^{*}$ Doç. Dr., Karamanoğlu Mehmetbey Üniversitesi, Edebiyat Fakültesi, Türk Dili ve Edebiyat1 Bölümü.

e-posta: kagiynas@gmail.com
} 
“Zâtî ve Tanpınar Diyor Ki: Şiirimiz Âb-ı Hayâtımızdır” başlığını taşıyan dördüncü yazıda yazar, Zâtî ve Tanpınar üzerinden sanatın ve şiirin ölümsüz olduğu ve şairlerin dönemlerindeki yöneticileri de ölümsüzleştirdiği üzerinde duruyor.

Beşinci yazının başlığı "Fuzûlî Soruyor: "Mal Deyince Ne Anlıyorsunuz?”dur. Yazar, "mal" kelimesinin etimolojisine değindikten sonra Fuzûlî'nin eserlerinden örneklerle insanın aslında birilerine bir şeyler verdikçe; yani malını harcadıkça tamamlandığını ve böylece zevale uğramaktan kurtulduğunu anlatıyor.

İlginç bir yazı olan altıncı yazı "Gelibolulu Âlî Diyor Ki: Bizim de Çalar Saatlerimiz Vardı" başlığını taşıyor. "Tezkire"nin ne olduğuyla ilgili bilgiden sonra Gelibolulu Âlî'nin Künhü'l-Ahbâr adlı eserinin tezkire kısmında bir şairin biyografisinde çalar saatten bahsediliyor. Çalar saatin tam olarak hangi tarihte kullanıldığı belli değilken 1500'lü yıllarda kaleme alınan bir eserde çalar saatten bahsedilmesi durumu ilginç bir hâle getiriyor.

Yedinci yazının başlı̆̆ı "Bir Osmanlı Âlimi Der ki: "Türk ile Kürd Kürd ile Türküm, Altı Dilde Gazel Yazarım"dır. Yazıda, on altıncı yüzyılda yaşamış bir şair olan Bitlisli Şükrî’nin zamanın padişahı Yavuz Sultan Selim'e şiir şeklinde sunduğu özgeçmişinden bahsediliyor.

Sekizinci yazı "Fuzûlî Diyor Ki: "Bin Diken Bir Gül İçin Sulanır” başlığını taşımaktadır. Yazar, bu yazıda Fuzûlî’nin Su Kasidesi'ndeki

\section{Ârızın yâdıyla nemnâk olsa müjgânım n'ola}

\section{Zâyi olmaz gül temennâsıyla vermek hâre su}

beytini eğitim açısından ele alıyor. Buna göre, bahçıvanın bir gül elde etmek için dikenleri sulayıp onlara özenle baktığı gibi öğretmenin de öğrencilerine itinayla, sabırla, ayrım yapmaksızın, eşit bir şekilde yaklaşması gerektiği ifade ediliyor.

"Bâkî Diyor Ki: Bizi Yağmalamayın Yahut Dişlerinizi İyi Fırçalayın” başlıklı dokuzuncu yazı, Bâkî hakkında hep basmakalıp ifadelerin kullanıldığı, sadece şairliğinden bahsedildiği, aynı zamanda mensur eserlerinin de bulunduğuyla başlıyor. Devamında Bâkî'nin mensur eserlerinin hâlâ hakkıyla incelenip yayımlanmadığı belirtiliyor. Son olarak da Bâkî'nin Hz. Peygamber'i konu edinen Me'âlimü'l-Yakîn'inde peygamberimizin vefatından hemen önce dişlerini misvakladığı hâlde bunun birçok siyer kitabında ele alınmadığına değiniliyor.

Onuncu yazı "Latîfî Der Ki: Kitap Yüz Yapraklı Bir Güldür” başlığını taşıyor. Yazar, bu yazıda Alberto Manguel'in Geceleyin Kütüphane adlı kitabı vesilesiyle haberdar olduğu Latîfî’nin "kitâb" redifli gazelini inceliyor.

"Divan Şairi Diyor Ki: Baklava Bizimdir" başlıklı on birinci yazısında yazar günümüzde devam eden "baklavanın hangi millete ait olduğu tartışmaları"na asırlar önce divan şairlerinin cevap verdiklerini belirtiyor. Baklavanın bize ait olduğu Zâtî, Lebîb, Rahmî, Nazmî, Vecdî, Cinânî ve Tırsî'den örneklerle anlatılıyor.

“Divan Şairi Diyor Ki: Bizim Elmalara Ne Oldu?" başlığını taşıyan on ikinci yazıda meyve adlarının hep yabancı olduğuna değinildikten sonra, neden yerli adlarla anılmadığı sorgulanıyor. Devamında Tezkire-i Rızâ'nın da müellifi olan Seyyid 
Mehmed Rıâ'nın Kızanlık Kasidesi'nde otuz beş farklı elma adının geçtiği ifade ediliyor.

On üçüncü yazı "Divan Şairi Diyor Ki: Bizde İktidarın Edebiyatı Değil, Edebiyatın İktidarı Vardı” başlığını taşıyor. Bu yazıda Osmanlı'da şair ve yazarların iktidarın yönlendirmesinde olmadıkları, sanatlarını özgür bir biçimde icra ettikleri anlatılmaktadır.

"Divan Şairi Diyor Ki: Bizim de Çocuk Eğitimimiz Vardı" başlıklı on dördüncü yazıda çocuk eğitimiyle ve edebiyatıyla ilgili yazılan eserlerde hep bu tür çalışmaların Batı'da başladığının söylenildiğine değiniliyor ve aslında öyle olmadığı, bizim de bu konularda kaleme alınmış metinlerimiz olduğu anlatılıyor.

On beşinci yazı "Tezkire Yazarı Diyor Ki: Mahlasların Anlamı Dilimizin Perdelerindendir" başlığını taşımaktadır. Yazar, bu yazıda önemli bir tespitte bulunuyor. O da şudur: Tezkire yazarı biyografi yazacağı şairin mahlası ve mesleği neyse ona göre bir dil kullanmaktadır.

"Şair Diyor Ki: Rüyayla Gelen Kitaplar Vardır" başlığını taşıyan on altıncı yazı yazarın da ilk cümlede söylediği gibi "yazarları tarafından rüyada kendilerine ilham edilerek yazıldığı söylenen metinlere dikkat çekmeye dair"dir.

On yedinci yazının başlığı "Divan Şairi Nâbî Der ki: Popülizm Kurbanı Olmayın"dır. Bu yazıda 17. yüzyıl şairlerinden Nâbî'nin, çağdaşı Sâbit'i zamanın modası olan şiirde atasözü kullanmayı abarttığı için eleştirdiği anlatılmaktadır. Nâbî'ye göre "Şiirde atasözü kullanmak hoştur; ancak marifet şairin kendisinden sonraya kalacak atasözü değerinde sözler söylemesidir":

\section{Sözde darbü'l-mesel îrâdına söz yok ammâ}

Söz odur âleme senden kala bir darb-ı mesel

On sekizinci yazıda çeşitli eserlerden örnekler sunularak, günümüz tıbbının "uyku yedi saatten az, dokuz saatten de fazla olmamalı" tespitinin asırlar önce eserlerimizde anlatıldığına değiniliyor. Yazının başlı̆̆ "Divan Şairi Diyor Ki: İdeal Uyku Nasıl ve Kaç Saat Olmalı?’dır.

On dokuzuncu yazıda çocuk eğitimiyle ilgili muhtelif şahsiyetlerin hayatlarından kesitler anlatıldıktan sonra Güvâhî'nin Pend-nâme'si ile Nâbî'nin Hayriyye'sinden çocukların eğitimine dair örnekler verilmiştir. Yazı "Güvâhî ve Nâbî Diyor Ki: Çocuğunuzu İşte Böyle Eğitin” başlığını taşımaktadır.

"Nedim Diyor Ki: Yapım Güzeldir; Orhan Veli Diyor Ki: Yıkım Güzeldir" başlıklı yirminci yazıda tarihî eserlere gereken ihtimamın gösterilmesi gerektiği Nedîm'in şiirleri ve Orhan Veli'nin bir şiiri incelenerek anlatıllyor.

Yirmi birinci ve sonuncu yazının başlığı "Şeyh Gâlib Der Ki: Zevki Kederde Sıkıntıyı da Rahatta Bil"dir. Bu yazıda yazar bir işi başarmak ve sonlandırmak için onu dert edinmek gerektiğine değiniyor.

Kitap, akademik anlatımın sıkıcılığı ve kuruluğundan uzak, sohbet havasında yazılmış yazılardan oluşuyor. Bütün bu yazıları okuyunca yazarın çok geniş bir 
okuma dünyasının olduğunu ve divan şiirini hakkıyla anlamak/anlatmak için disiplinler arası okumalar yapılması gerektiğini anlıyoruz.

$\mathrm{Bu}$ değerlendirmelerime ek olarak kitapla ilgili birkaç eleştiri yapmadan geçemeyeceğim. Sayfa 58' de "Şeyhî: Şiir, Ölümsüzlüğe Erdiren Bir Âb-1 Hayattır" başlı̆̆ı var. Başlıkta Şeyhî’nin adı geçmesine rağmen Zâtî’nin gazeli yer alıyor. Birçok yerde eklerin eksikliğinden kaynaklanan cümle bozuklukları var. Yer yer yazım yanlışları, anlatım bozuklukları, dipnot karışıklıkları ve imla tutarsızlıkları da göze çarpıyor. Bunların ilerideki muhtemel baskılarda düzeltileceğini umuyorum.

Son olarak farklı dergilerde muhtelif zamanlarda yayımlanmış yazılarını bir araya getirip bizlere sunan Dursun Ali TÖKEL'e teşekkür ediyorum. 